ПЕДАГОГІКА ПАРТНЕРСТВА В ОСВІТНЬОМУ СЕРЕДОВИЩІ РОМСЬКОГО НАСЕЛЕННЯ

Лабош К.

\title{
PEDAGOGY OF PARTNERSHIP IN THE EDUCATIONAL ENVIRONMENT OF THE ROMA POPULATION
}

Labosh Christina

У статті висвітлено основні сфери дискримінації ромської національної мениини (освіта, житлові умови, охорона здоров'я, прачевлаштування, сочіальне забезпечення тошьо). Представлено основні тенденції освіти $i$ культури національних меншин Закарпаття,зокрема на прикладі ромського населення, охарактеризовано поняття “національні меншини”. Розкрито сутність педагогіки партнерства в освітньому середовищі ромського населення. Проведено аналіз формування та рівня забезпеченості освітою ромської етнічної спільноти Закарпаття. Проаналізовано культурно-освітній стан національних меншин області, задоволення їхніх наџіональних потреб, збереження і розвиток культурних традииій.

Ключові слова: національні меншини, освіта, педагогіка партнерства, ромське населення, культура, освітнє середовище.

The article highlights the main areas of discrimination against the Roma national minority (education, housing, health care, employment, social security, etc.). The main tendencies of education and culture of national minorities of Transcarpathia are presented, in particular on the example of the Roma population, the concept of "national minorities" is characterized. The essence of partnership pedagogy in the educational environment of the Roma population is revealed. An analysis of the formation and level of education of the Roma ethnic community in Transcarpathia. The cultural and educational condition of national minorities of the region, satisfaction of their national needs, preservation and development of cultural traditions are analyzed.

Key words: national minorities, education, partnership pedagogy, Roma population, culture, educational environment.

В Україні йде обговорення питання щодо концепції мовної політики, яке торкається всіх національностей, які проживають на теренах нашої області. На основі вивчення публікацій, спеціальної літератури 3 даної теми розглянемо педагогіку партнерства та проаналізуємо культурно-освітній стан ромського населення з результатів раніше проведених досліджень, зокрема проаналізуємо формування освітнього середовища серед представників ромського етносу у Закарпатській області.

Про етносоціальні та етнокультурні та освітні процеси ромського населення Закарпаття можемо знайти у працях: Адам А. Е., Навроцкая Е. М. Цыгане Закарпатья в посттоталитарный период (по материалам периодической областной пресы) [1], Євтух В. Етносоціальні процеси в Україні. Можливості наукових інтерпретацій [3], Смець Г., Мигович I. Цигани на Закарпатті: проблеми соціалізації [4], Навроцька Є. М. Цигани Закарпаття в посттоталітарний період. Матеріали науково-практичної конференції -Державне регулювання міжетнічних відносини в Закарпатті [5], Lehoczky T. A munkacsi cziganyok [6].

Метою даної статті $\epsilon$ вивчення педагогіки партнерства представників етнічної меншини Закарпатської області ромського населення. Зокрема окреслити назрілі етносоціальні, етнокультурні та освітні проблеми ромського населення.

Проблеми інтеграції, виховання та духовного розвитку особистості у громадянському 
суспільстві ромської національної меншини другої половини XX - поч.. XXI ст. надзвичайно складне і багатогранне. Адже ромське населення Закарпатської області характеризується дуже низьким рівнем освіти. Значна частина їх $\epsilon$ неграмотною та не має жодної освіти. За даними перепису 2001 р. серед закарпатських ромів вищу освіту мали 0,02 \% населення, середньоспеціальну $0,2 \%$, середню $3,8 \%$, неповну середню $17,1 \%$. Лише початкову освіту мали 49,3 \% ромів Закарпаття, а більше $25 \%$ не мали жодної освіти. За даними перепису 2001 року, у Закарпатській області налічувалося 2327 мононаціональних ромських домогосподарств 312390 особами (88,5 \% ромського населення Закарпаття). Середній розмір ромського домогосподарства становив 5,6 осіб (середнє по регіону - 3,9 осіб), що є найвищим показником серед всіх найбільших національностей не тільки Закарпатської області, але й всієї України. Закарпаття є єдиним регіоном України, де ромська мова є рідною для незначної частки ромського населення (20,5\%). Рідною мовою більшості ромів Закарпаття є угорська, яку назвали рідною майже $2 / 3$ ромів області. Майже виключно угромовними $\epsilon$ роми Берегівського та Мукачівського районів, а також міст Берегова та Мукачева. Циганомовні роми переважають в Ужгороді, Хусті та частині населених пунктів Ужгородського та Виноградівського районів (напр., Середньому, Підвиноградові). Повністю україномовними $\epsilon$ роми Великоберезнянського та деяких інших гірських районів області. У Перечинському районі у населених пунктах Порошково та Тур'ї Ремети проживають волохи, етнічна група змішаного румунського і ромського походження, які розмовляють діалектом румунської мови. За даними офіційного перепису 1989 р. в Закарпатті проживало 12131 ромів, а за даними соціологічного дослідження з 15.04.1989 р. - понад 20 тис. [5].

Упродовж XX ст. соціально-політичне і культурно-побутове становище закарпатських ромів не зазнало істотних змін. Якщо владні органи АвстроУгорщини майже не займались проблемами ромів, то урядові чиновники Чехословаччини впродовж 20-30-х років проводили певні заходи господарського і культурно-просвітницького характеру. Вони пропагували i заохочували у них розвиток промислів і ремесел, перехід до осілості, організували навчання ромських дітей та інше. У роки окупації Карпатської України угорськими фашистами (19391944 рр.) власті проводили щодо ромів заходи репресивного характеру, що часом набирали форм прямого фізичного характеру.

Представники ромської національної меншини в Україні продовжують залишатися однією 3 найбільш вразливих соціальних груп, яка піддається систематичній маргіналізації, стигматизації та дискримінації.

Серед найбільших проблем, з якими стикаються роми в Україні, є ускладнений доступ до освіти, медицини, соціальних послуг і працевлаштування, відсутність ідентифікаційних документів. Серед соціально-економічних чинників, які найбільш негативно впливають на становище ромів, є низький рівень доходів, неналежні побутові умови, а також низька обізнаність щодо виховання, харчування, догляду за дітьми. В сукупності ці проблеми призводять до соціальної ізольованості ромської національної спільноти та обмеженості у реалізації прав

На сучасному етапі рівень освіти ромів залишається традиційно найнижчим, порівняно з іншими національними меншинами. Регулярно відвідує школу тільки близько 30\% їх дітей. Причому присутні вони у кращому випадку на 1-2 уроках в день. Показник регулярності знижується від мало - до багатодітних сімей (35-24 \%). Загалом по області, згідно опитування ромів, 83,7 \% їх діти одержали тільки неповну середню освіту, 14,5 \% загальну середню, 1,4 \% - закінчили СПТУ, 0,3 \% - здобули середню спеціальну і лише 0,1\% - вищу освіту. Відносно краще з освітою ромів в Ужгороді, Мукачеві, Ужгородському та Свалявському районах. Як показує аналіз, 43,3 \% ромських сімей мають бажання дати своїм дітям неповну середню, 43,5 \% - загальну середню, 8,6 \% - середню спеціальну і лише 0,5 \% - вищу освіту.

Отже, невисокий освітній рівень батьків трансформується на дітей. Як результат, більша частина ромської молоді з різних причин залишається осторонь освіти, що значно 
звужує можливості реалізації їі життєвих інтересів.

Педагогіка партнерства - напрям педагогіки, що включає собою систему методів і прийомів виховання і навчання на засадах гуманізму та творчого підходу до розвитку особистості. В основі педагогіки партнерства - спілкування, взаємодія та співпраця між учителем, учнем і батьками. Учні, батьки та вчителі, об'єднані спільними цілями та прагненнями, є добровільними й зацікавленими спільниками, рівноправними учасниками освітнього процесу, відповідальними за результат. Учитель має бути другом, а родина залучена до побудови освітньої траєкторії дитини. Педагогіка партнерства визначає істинно демократичний спосіб співпраці педагога і дитини, який не відкидає різниці в їхньому життєвому досвіді, знаннях, але передбачає безумовну рівність у праві на повагу, довіру, доброзичливе ставлення і взаємну вимогливість [2].

Сучасне навчання і виховання учнів вимагає нової педагогічної етики, визначальною рисою якої $є$ взаєморозуміння, взаємоповага та творче співробітництво вчителя та учня. Ця етика утверджує не рольове, а особистісне спілкування (підтримка, співпереживання, утвердження людської гідності, довіра); зумовлює використання особистісного діалогу як домінуючої форми навчального спілкування, спонукання до обміну думок, вражень, моделювання життєвих ситуацій; включає спеціально сконструйовані ситуації вибору, авансування успіху, самоаналізу, самооцінки, самопізнання. Принципово важливою $\epsilon$ орієнтація партнерської діяльності вчителя та учня на розвиток творчості - творчої активності, творчого мислення, здібностей до адекватної діяльності в нових умовах.

Громадяни ромської національності найменше, ніж інші нацменшини, інтегровані в українське суспільство. Внаслідок цього вони щоденно стикаються з багатьма соціальними проблемами, $є$ найбільш дискримінованою групою населення. Ці факти визнають і самі роми, i представники влади. Водночас наголошують, що однією з головних перешкод на шляху ромів до інтеграції в українське суспільство є відсутність освіти. Зважаючи на ці фактори, а також на взятий Україною у процесі іiі розвитку євроінтеграційний вектор, що визнає дотримання прав національних меншин як одну з основних цінностей, 2103 року в Україні було затверджено Стратегію захисту та інтеграції в українське суспільство ромської національної меншини на період до 2020 року. Таким чином інтеграцію ромів було визнано соціально значущим питанням на державному рівні.

Згідно $з$ проведеним в Україні 2015 року соціологічним опитуванням ромів, чимало представників ромської національності (23\%) взагалі не вміють писати та читати, що негативно впливає на їх рівень життя. 24\% респондентів взагалі не мають будь-якої освіти, а найбільш поширенішою серед них є неповна середня (37,2\%). Частка ж людей, які отримали чи отримують на даний момент вищу освіту, є взагалі мізерною - лише 1\%. Дані з інших джерел свідчать, що лише $6 \%$ ромів України здобули професійно-технічну чи повну загальну середню освіту, а понад $90 \%$ так і не отримали повної освіти у навчальних закладах. Тому, на жаль, освітній рівень серед представників ромської меншини є найнижчим в Україні.

3 причин недостатньої освіти або взагалі їі відсутності більшість ромів фактично відокремлені від суспільства та відрізані від широкого кола можливостей, доступних для більшості громадян. Приміром, таких як отримання соціальної допомоги від держави, захист своїх прав та користування ними, перспективи у пошуках роботи. За відсутності освіти чимало ромів приречені до кінця свого життя шукати роботу, що не вимагає певної кваліфікації або передбачає тяжку та низькооплачувану фізичну працю, а це у свою чергу виключає будь-які зрушення в соціальному положенні чи професійний розвиток у майбутньому. Така перспектива жодним чином ані на крок не наближує ромів до соціалізації та отримання рівних можливостей із самореалізації на рівні з іншими громадянами України, а лише збільшує ступінь їх маргіналізації у суспільстві та, як наслідок, асоціальної поведінки. I так - із покоління в покоління.

У Закарпатській області - приблизно 159 загальноосвітніх закладів, у яких ромські діти здобувають освіту. Серед них - 6 шкіл, де навчаються виключно діти-роми (міста 
Ужгород, Мукачево, Берегово, Свалявський та Хустський райони) та 15 шкіл, у яких є окремі класи для ромських дітей (місто Чоп, Виноградівський, Іршавський, Ужгородський, Рахівський райони,). Та переважна більшість маленьких ромів навчається разом 3 дітьми інших національностей. Загалом кількість школярів на Закарпатті має тенденцію зменшуватися, але учнів ромської національності з кожним роком в області стає все більше.

У дискусіях щодо проблеми навчання ромів побутує поширена думка, що, мовляв, доступ до шкільної освіти $є$ рівним для усіх громадян незалежно від їх етнічної приналежності та соціального положення. За такою логікою, якщо батьки за певних причин не бажають віддавати до школи своїх дітей або хоча б стежити за їх освітнім процесом, а діти, які таки числяться у школі, але системно не відвідують занять, то це буцімто - їхне бажання. I ніхто не має права примушувати їх, адже «в них така культура» або «вони не здатні до навчання тільки тому, що вони роми».

Але, як доводить практика, такі думки переважно висловлюють люди, які, по-перше, вже мають упереджене ставлення до ромської національності з власних причин, не розуміють i не бажають розуміти, навіщо інтегрувати особливо вразливу групу у суспільний процес побудови рівноправної держави без дискримінації та з рівними для всіх можливостями, а, подруге, геть нічного не знають про ромську історію та культуру, апелюючи до того, що «роми завжди обирали такий спосіб життя і не мають бажання його жодним чином змінювати».

Згідно з Конституцією України та Законом України «Про загальну середню освіту», повна загальна середня освіта $\epsilon$ обов'язковою, а держава зобов'язана всіляко забезпечувати їі безоплатність та доступність для всіх громадян без винятку, незалежно від їх раси, національності, кольору шкіри, віросповідання, соціального статусу чи матеріального положення.

Проте, яким би красномовним не був головний документ держави, стан освіченості ромів за часи його існування та правової дії докорінно так і не змінився. I справа не в наведених вище причинах, а в самому контексті ромської проблематики. Якщо докладніше розглянути це питання, стає зрозумілим, що роми неабияк здібні до навчання. Але побудова освітнього процесу вимагає нових креативних підходів та залучення нових дієвих осіб у двосторонніх відносинах між ромськими батьками й дітьми $з$ одного боку та державною політикою й школою - 3 іншого.

Прийнято вважати, що головним лобістом у здобутті освіти дитини мають виступати ії батьки. Маючи певну батьківську владу та авторитет, вони впливають на дітей, відіграють для них роль найважливішого джерела інформації та головного форматора ціннісного світогляду. Як наслідок, на батьківських плечах - велика відповідальність за своїх дітей та їх безпосереднє майбутнє. Тому навряд чи можна сказати, що батьки, чиї діти з певних причин належно не навчаються у школах, бажають їм поганої долі. Зовсім ні. Але через низку причин ромські діти так і не отримують повної середньої освіти.

Головним напрямком роботи 3 поліпшення статистики освіченості серед ромів має стати поширення мотивації до навчання, а також просвітництво щодо переваг здобуття освіти як серед самих дітей, так і серед їхніх батьків. Не здобувши самі повної шкільної освіти, деякі батьки можуть просто не усвідомлювати важливість навчання у школі для подальшого життя дитини та перспектив іiі гідного працевлаштування й саморозвитку. Цікаво, що, згідно 3 опитуванням, чим більш освіченими є батьки, тим більше ймовірність, що їхня дитина не має проблем з відвідуванням шкільного закладу.

Однак деякі дорослі вважають, що створення сім'ї та робота змолоду для ромів є більшими пріоритетами. А відтак не надто зацікавленні в освіті власних дітей через брак розуміння того, яким цінним інвестуванням у майбутнє це $\epsilon$, i що освічена дитина матиме набагато більше можливостей реалізувати себе у професійній діяльності та стати частиною українського суспільства.

Говорячи про проблеми освіти ромів, важливо зауважити, що на їх шляху до отримання освіти, порівняно з представниками інших національностей, існує багато перепон. 
Левова частка ромських сімей живе за межею бідності і фактично соціально ізольована від суспільства, а тому деякі звичні речі та послуги для ромів $є$ недоступними саме через скруту[8].

Наприклад, щоб віддати дитину до школи, треба купити неабияку кількість речей: портфель, шкільну та спортивну форму, підручники, зошити, канцтовари. Також поширеною $\epsilon$ практика, коли (хоча навчання і $є$ безкоштовним), від батьків вимагають щомісячні внески у фонд школи. I якщо навіть для багатьох українських родин такі витрати б'ють по сімейному бюджету, то для більшості ромських сімей вони є непід'ємними. I це, на жаль, робить освіту для ромських дітей менш доступною, аніж для інших.

Крім бідності, свою роль відіграє також чинник дискримінаційного ставлення до ромів у суспільстві. Тож, батьки дуже часто замислюються: «А чи варто віддавати дитину до школи, де іï будуть перед усім класом принижувати вчителі, а на перерві однолітки сміятимуться з неї?»

На Закарпатті є школи, де навчаються тільки діти ромської національності. Приміром, школа №13 в Ужгороді - iї відвідують 320 учнів із трьох місць компактного поселення, розташованих поблизу навчального закладу. Оскільки діти у цій школі є представниками однієї культури, вони почуваються тут захищено та більш комфортно, ніж в інших, де навчаються не тільки роми. Однак у такому випадку вони фактично уникають спілкування 3 представниками інших культур та народностей, що лишає дітей можливості соціалізуватися і пізнавати навколишній світ поза простором, де вони звикли відчувати себе звично. Така ситуація $\epsilon$ компромісною: 3 одного боку, роми отримують освіту, але 3 іншого, не інтегруються через взаємодію 3 дітьми, які є представниками інших культур, цінностей, поглядів, соціальних прошарків та інтересів. Це не сприяє порозумінню між ними та, навпаки, лише «консервує» поточний стану справ щодо сегрегації у суспільстві та поділу людей на своїх і чужих.

У травні 2017 року, директор школи та ром за національністю. До цього він працював з ромськими дітьми в інших школах, де йому вдалось налагодити особистий контакт з учнями і в рази покращити відвідуваність уроків. Головним кроком до поліпшення стану освіти у ромській громаді, має стати порозуміння між учнями та вчителями, що, в першу чергу, залежить від волі останніх.

«Ромські діти відрізняються від інших однолітків своїм світосприйняттям та умовами, в яких проживають. Тому освітня робота 3 ними вимагає нових підходів у методиці та креативних практик у викладанні. Доволі часто вчителі дійсно сприймають ромів як «особливих», а тому можуть не вимагати від них блискучого знання матеріалу, вважаючи, що таким дітям достатньо лише вміти писати й читати. Такий підхід є докорінно невірним, адже, хоча всі діти є різними, але це не означає, що ромські діти - гірші або менш здатні до навчання»[9], - вважає педагог.

Керівник благодійного фонду «Серце з любов’ю», спрямовує свої зусилля на допомогу вихованцям та випускникам шкіл-інтернатів, дітям-сиротам, інвалідам та дітям 3 малозабезпечених сімей Закарпатської області, а також «важким» підліткам. «Фонд забезпечує їх правовий та соціальний захист, полегшує адаптаційний період до самостійного життя. Надаємо моральну та матеріальну підтримку таким дітям під час подальшого навчання, працевлаштування, лікування та отримання житла і реєстрації». Крім того, завдяки діяльності фонду діти 3 малозабезпечених сімей отримують необхідні для школи речі, які не мають можливості придбати їхні батьки: ранці, зошити, олівці, ручки та інше.

Рік тому фонд розпочав проект «Освіта ромів - запорука їх успішності у суспільстві», в рамках якого у селі Порошково Перечинського району Закарпатської області. Центр покликаний не лише спонукати ромські сім'ї віддавати дітей до школи, але й допомагати дітям адаптуватися до неї, не пропускати уроків та отримувати якісну середню освіту. Завдяки цьому діти можуть додатково займатися з педагогом, психологом, розвивати свої творчі здібності та відпочивати у зручному та дружньому для них середовищі. 
Чотири рази на тиждень 3 дітьми працюють психолог та педагог-координаторка. Вони ведуть додаткові заняття 3 підготовки до уроків, групу продовженого дня, а також здійснюють виїзні консультації та анкетування у ромській громаді. дуже важливо налагодити особистий контакт 3 дитиною з одного боку й просвітницьку роботу з батьками - 3 іншого. Ромська культура визначає сімейні відносини як одну з головних своїх цінностей, а тому налагодження зв'язку між школою, директором, учителем та ромськими сім'ями є вкрай важливим.

Особливої уваги заслуговує проведений у школі №13 експеримент, під час якого відбувся обмін викладацьких колективів між школами міста. Ідея його проведення виникла під час обговорення між представниками влади та директорами шкіл покращення методів освіти у ромських громадах та причин неефективності діючої методології. Під час експерименту вчителі з інших шкіл мали можливість провести заняття 3 ромськими дітьми замість постійних викладачів і, навпаки, вчителі зі школи №13 провели уроки для дітей 3 інших шкіл[10].

Розповідаючи про експеримент, начальниця департаменту управління освіти в місті Ужгород відзначила, що така нестандартна спроба дослідити причини низького рівня освіти ромів дуже збагатила кращим розумінням реальної ситуації усіх, хто зацікавлений у ії поліпшенні. 8 завучів й директорів інших шкіл того дня провели заняття з ромськими учнями школи №13 і на власні очі побачили, наскільки знання школярів не відповідають рівню того класу, в якому вони навчаються.

Проте викладачі побачили й інше - те, що їх здивувало та надихнуло на подальшу роботу: ромські діти виявилися дуже здібними, слухняними та склали враження таких, що дійсно хочуть навчатися. Але, за словами учасників експеременту, він виявився успішним лише через підвищений рівень уваги до дітей з боку викладачів. Вони дуже сумлінно готувалися до проведення занять та вигадували нові креативні підходи по роботі з дітьми, що дозволило максимально сконцентрувати увагу та збільшити залучення дітей до процесу навчання. Зі слів начальника департаменту освіти в місті Ужгород, лише 35 дітей із 350, зарахованих до шкіл, систематично відвідують заняття. Та завдяки активній роботі 3 залучення дітей до експерименту, у день його проведення більшість учнів була присутня, а за результатами спостерігали батьки та представники ромських громадських організацій. Велику роль у покращенні стану освіти ромів відіграють недержавні інститути, а саме громадські організації, благодійні фонди, ромські лідери та, як не дивно, церква. Через кращу обізнаність у проблематиці та культурі ромів їм разом вдається будувати всеосяжну стратегію із залучення ромів до освітнього процесу.

Велику роботу зі спонукання батьків відповідально ставитися до освіти дітей ведуть ромські лідери. Як правило, вони мають тісні контакти безпосередньо з ромами у громаді, мають серед них певний автортет, до їх думок дослухаються і сприймають це як позитивне менторсво. Такий стан речей допомагає активістам працювати на благо громади, переконуючи батьків, що освіта - квиток їхньої дитини до кращого, цивілізованого життя[11].

Секрет вдалої комунікації між ромською громадою та освітніми закладами полягає у постійному відвідуванні ромських поселень та в особистому спілкуванні 3 сім'ями. Працюючи на благо своєї громади в Ужгородській міськраді, працівники щоденно спілкуються з мешканцями багатьох місць компактного поселення в Ужгороді та першими дізнаються про ситуацію в них, тому оперативно вирішують різні питання у рамках своєї депутатської діяльності. Адже дуже важливо систематично відвідувати шкільні збори за для того, щоб бути обізнаним з ситуацією в освіті, а також заохочувати дітей-ромів до навчання через проведення різних культурних заходів та святкових подій.

Чимало активістів, залучених до процесу покращення ситуації з освітою ромів, зазначають, що на Закарпатті дуже важливу ролу у спонуканні ромських батьків до відповідального ставлення до освіти своїх дітей відіграє інститут церкви. Зараз на Закарпатті 
функціонує близько 100 церков, переважно євангелістського спрямування. Справа в тім, що роми - у своїй більшості дуже релігійні люди, тому і прислухаються до настанов пасторів навчатися та жити згідно з законами Біблії.

Це свідчить про те, що стереотип про неосвічених ромів потроху ламається. I все більше молодих людей, розуміючи цінність навчання у вищому навчальному закладі, прямують до успішної кар'єри у найрізноманітніших областях, зокрема, у сфері юриспруденції, і зрештою успішно інтегруються в українське суспільство.

Не зважаючи на активну участь недержавних інститутів (фондів, громадських організацій) у ромському освітньому процесі та позитивні зміни у цьому напрямку, статистика все ще свідчить про наступне: для того, аби ромська національна меншина в Україні зрівнялася за рівнем освіти з іншими громадянами, усім сторонам слід спрямовувати на це набагато більше сил та ресурсів.

А головне - глибоко розбиратися в особливостях культури й ментальності цього народу, аби мати змогу застосовувати нові креативні підходи і практики у державній політиці щодо інтеграції ромів.

Ромська етнічна меншина Закарпаття істотно відрізняється від інших спільнот особливостями своєї життєдіяльності, етнокультурної мобілізації і етно менталітету. Ця специфіка виявляється, насамперед, у низькому освітньому рівні, який зумовлюється низкою чинників. Найбільш істотним із них уважаємо недостатню готовність батьків налагоджувати педагогіку партнерства та вчитись спільно працювати 3 вчителем та своєю дитиною. Відповідно, вивчення етносоціального й етнокультурного життя, специфіки освітнього питання даної національної меншини Закарпаття - важлива комплексна науково-теоретична $\mathrm{i}$ предметно-практично проблематика, яка потребує подальшого грунтовного вивчення.

\section{Список використаних джерел}

1. Адам, А. Е. Цыгане Закарпатья в посттоталитарный период (по материалам периодической областной пресы) [Текст]: матер. наук.прак. конф. / А. Адам, Е. Навроцкая // Державне регулювання міжетнічних відносини в Закарпатті. - Ужгород, 1997. - С. 123-129.

2. Вишневський О. Теоретичні основи сучасної української педагогіки : Посібник для студентів вищих навчальних закладів. / О. Вишневський - Дрогобич : Коло, 2006. $326 \mathrm{c.}$

3. Свтух, В. Етносоціальні процеси в Україні. Можливості наукових інтерпретацій [Текст] / В. Свтух. - К., 2004. - 242 с.

4. Ємець, Г. Цигани на Закарпатті: проблеми соціалізації. [Текст] / Г. Ємець, І. Мигович // Карпатський край. - 2001. - № 1(30). - С. 18-24.

5. Навроцька, Є. М. Цигани Закарпаття в посттоталітарний період [Текст]: матер. наук.прак. конф. / С. Навроцька // Державне регулювання міжетнічних відносини в Закарпатті. - Ужгород, 1997. - С. 116-122.

6. Lehoczky, T. A Munkacsi cziganyok [Text] / T. Lehoczky // Etnographia, t. XVI./T. Lehoczky - Budapest, 1905. - $189 \mathrm{p}$

7. Народне господарство Закарпатської області. Статистичний збірник [Текст]. Ужгород, 1980. - 94 с.

8. Вишневський О. Теоретичні основи сучасної української педагогіки : Посібник для студентів вищих навчальних закладів. / О. Вишневський - Дрогобич : Коло, 2006. $326 \mathrm{c}$.

9. Матеріали науково-практичної конференції -Державне регулювання міжетнічних відносини в Закарпатті. Статистичні дані. Додатки [Текст]. - Ужгород, 1977. - С. 213 235.

10. Народы мира. Историко-этнографический справочник [Текст]. - М., 1988. - 644 с. 14. Національний склад населення Закарпатської області (згідно перепису 1989 року) 
[Текст]: матер. наук.- прак. конф. // Державне регулювання міжетнічних відносин в Закарпатті. - Ужгород, 1997. - 78 с

11. Питюлич М. Занятость цыганского населения в новых условиях хозяйствования / М. Питюлич // Экономика Украины._-1993._ №5.-С. 89-92.

12. Школьное образование для цыганских детей // Курьер ЮНЕСКО - 1984.—Ноябрь.C. 3

\section{References}

1. Adam, A. E., Navroczkaya, E. 1997. Czygane Zakarpat`ya v posttotaly`tarnyj pery`od (po matery`alam pery`ody`cheskoj oblastnoj presy) [Gypsies of Transcarpathia in the posttotalitarian period (based on materials from the periodic regional pres)]. Conference. Sovereign regulation of major issues in Transcarpathia Derzhavne regulyuvannya mizhetnichny`x vidnosy`ny` v Zakarpatti. Uzhgorod, P. 123-129.

2. Vy`shnevs`ky`j, O. 2006. Teorety`chni osnovy` suchasnoyi ukrayins`koyi pedagogiky [Theoretical foundations of modern Ukrainian pedagogy]. Drogoby`ch, Kolo, $326 \mathrm{p}$.

3. Yemecz', G. ', My`govy`ch, I. 2001. Cy`gany` na Zakarpatti: problemy` socializaciyi [Gypsies in Transcarpathia: problems of socialization]. Carpathian region. N. 1(30), P. 1824.

4. Navrocz ka, Ye. M. 1997. Cy`gany`Zakarpattya v posttotalitarny`j period [Gypsies of Transcarpathia in the post-totalitarian period]. Conference. State regulation of interethnic relations in Transcarpathia. Uzhgorod, 1997, P. 116-122.

5. Lehoczky, T. A. 1905. Munkacsi cziganyok [Munkachi breakfast]. Ethnography. Vol. 16. Budapest, $189 \mathrm{p}$.

6. 1980. Narodne gospodarstvo Zakarpats`koyi oblasti. Staty`sty`chny`j zbirny`k [National economy of the Transcarpathian region. Statistical collection]. Uzhgorod, $94 \mathrm{p}$.

7. Vy`shnevs`ky`j, O. 2006. Teorety`chni osnovy` suchasnoyi ukrayins`koyi pedagogiky` [Theoretical foundations of modern Ukrainian pedagogy]. Drogoby`ch. Kolo, $326 \mathrm{p}$.

8. 1977. Derzhavne regulyuvannya mizhetnichny`x vidnosy`ny`v Zakarpatti. Staty`sty`chni dani. Dodatky' [State regulation of interethnic relations in Transcarpathia. Statistics. Additions]. Conference. Uzhgorod, P. 213-235.

9. 1988. Narody mira. Istoriko-etnograficheskiy spravochnik [The peoples of the world. Historical and Ethnographic Handbook]. Moscow, 644 p.

10. 1997. Nacional`ny`j sklad naselennya Zakarpats`koyi oblasti (zgidno perepy`su 1989 roku) [National composition of the population of Zakarpattia region (according to the 1989 census)]. Conference. State regulation of interethnic relations in Transcarpathia. Uzhgorod, $78 \mathrm{p}$.

11. Pityulich, M. 1993. Zanyatost' tsyganskogo naseleniya v novykh usloviyakh khozyaystvovaniya [Gypsy population employment in the new economic conditions]. Economy of Ukraine. N. 5, P. 89-92.

12. 1984. Shkol'noe obrazovanie dlya tsyganskikh detey [School education for Roma children]. UNESCO Courier. November, P. 3. 